Man and Nature

L'homme et la nature

\title{
The Poet and Affairs of State in Johnson's Lives of the Poets
}

\section{Howard Erskine-Hill}

Volume 6, 1987

URI : https://id.erudit.org/iderudit/1011873ar

DOI : https://doi.org/10.7202/1011873ar

Aller au sommaire du numéro

Éditeur(s)

Canadian Society for Eighteenth-Century Studies / Société canadienne d'étude du dix-huitième siècle

ISSN

0824-3298 (imprimé)

1927-8810 (numérique)

Découvrir la revue

Citer cet article

Erskine-Hill, H. (1987). The Poet and Affairs of State in Johnson's Lives of the Poets. Man and Nature / L'homme et la nature, 6, 93-113.

https://doi.org/10.7202/1011873ar

Copyright (C Canadian Society for Eighteenth-Century Studies / Sociéte canadienne d'étude du dix-huitième siècle, 1987
Ce document est protégé par la loi sur le droit d'auteur. L'utilisation des services d'Érudit (y compris la reproduction) est assujettie à sa politique d'utilisation que vous pouvez consulter en ligne.

https://apropos.erudit.org/fr/usagers/politique-dutilisation/ 


\section{THE POET AND AFFAIRS OF STATE IN JOHNSON'S LIVES OF THE POETS}

'In the fate of princes the publick has an interest; and what happens to them of good or evil the poets have always considered as business for the Muse' (Lives of the English Poets, by Samuel Johnson, ed. George Birkbeck Hill (Oxford, 1905), I 424-5). This affirmation by Johnson, appropriately made in the 'Life of Dryden', suggests the importance of political affairs in the Prefaces, Biographical and Critical, to the Works of the English Poets (The Lives of the Poets). It is hardly true, as that formidable Johnsonian Donald Greene has argued ${ }^{1}$, that passages of political interest are to be found in only a handful of the Lives (Milton, Waller, Butler and Akenside): when one begins to look for them, they may be found, and the political dimension of the work is neglected in the chief recent discussions. ${ }^{2}$ Taking the biographical and critical together we may see not only how Johnson attends to political content in the texts of his poets, but also how he traces the ways in which poets, like it or not, had to seek their living in an unpredictable and often ungenerous political world. Johnson offers exemplary instances of poets maintaining or failing to maintain the moral independence of their muse through revolutions of various kinds, in war, usurpation, rebellion, change of dynasty and the proscription of a great national party. It is inevitable that his own judgement of the specific political events of the previous century and a half should have become part of the picture he draws. 
The Lives of the Poets $(1779,1781)$, I shall argue, is an important source for Johnson's political opinions. It shows the last phase of his views as they extend from three works of 1738-39, London, Marmor Norfolciense and A Compleat Vindication (1738, 1739), through the change of political system in 1760 , to his later years $(1779,1781)$. The brief exploration of the Lives I now offer is meant as a sequel to a recent essay, 'The Political Character of Samuel Johnson' in Isobel Grundy, ed. Samuel Johnson: New Critical Essays (London, 1984) in which I sought a closer definition of Johnson's eighteenth-century Toryism than we are usually offered and, on Non-Boswellian as well as Boswellian grounds, to reinstate the issue of Johnson's Non- Juring and Jacobite sympathies.

It would be possible to read Johnson's political and historical remarks as they occur in the final order of the Lives, from the birth of Cowley in 1618 to the death of Lyttelton in 1773, as a continuous commentary on the political history of England during that time. But that would be to respond to the Lives in an unjustifiably narrow and selective way. It is of course a sequence of narratives which holds firmly to its focus, the lives of poets, sometimes merely sketching a background of events, sometimes when the poet is at the centre of high politics, passing judgement in explicit and trenchant terms, sometimes (as Fussell and Folkenflik well show) conveying Johnson's view with a restrained and laconic irony that allows events to speak for themselves. While pursuing the political theme of the Lives it is necessary to respect Johnson's own sense of proportion and priority.

An early group of lives, Cowley, Denham, Milton, Butler and Waller, present poets involved in the English Civil War. Both Cowley and Denham served the royal family in war and exile and underwent danger at the hands of (Johnsonrds, I 9) 'the usurping powers'. But whereas at the Restoration Denham 'obtained that which many missed, the reward of his loyalty' (I 74), Cowley's hopes of 'ample preferments' were ignored in 'a time of such general hope that great numbers were inevitably disappointed' (I 13). To add to his mortification his newly revised comedy, The Cutter of Coleman Street failed in the theatre and was censured as 'a satire on the king's party' (I 14). At this time Butler's 'loyalty hoped for its reward' but he was only made secretary to the president of Wales (I 203).

Johnson's political views achieve high profile in the 'Life of Milton' and above all where the poet used his pen to justify the execution of King Charles and vindicate the record of the Lord Protector. Having employed his sarcasm on both Salmasius and Milton ('No man forgets his original trade: the rights of nations and of kings sink into ques- 
tions of grammar, if grammarians discuss them' (I 113) Johnson homes in on Cromwell and Milton:

Cromwell had now dismissed the parliament by the authority of which he had destroyed monarchy, and commenced monarch himself under the title of protector, but with kingly and more than kingly power. That his authority was lawful, never was pretended; he himself founded his right only in necessity: but Milton, having now tasted the honey of publick employment, would not return to hunger and philsophy, but, continuing to exercise his office under a manifest usurpation, betrayed to his power that liberty which he had defended. Nothing can be more just than that rebellion should end in slavery: that he, who had justified the murder of his king, for some acts which to him seemed unlawful, should now sell his services and his flatteries to a tyrant, of whom it was evident that he could do nothing lawful. (I 115-6)

Of the passage in the Second Defence beginning 'Deserimur, Cromuelle; tu solus superes ...' Johnson says: 'Caesar when he assumed the perpetual dictatorship had not more servile or more elegant flattery' (I 118). Johnson's political analysis, which comes close, in its stress on Cromwell's insecurity of position, to the conclusions of the modern, revisionist school of Civil War historiography, ${ }^{3}$ expresses what had been Church of England orthodoxy from the Restoration on. As Birkbeck Hill pointed out, however, he did not hesitate to heighten his denunciation. He had praised Shakespeare for making Claudius a drunkard as well as a usurper and murderer; ${ }^{4}$ here he passes over the modest private means which would have allowed Milton to give up public employment without hunger (I $116 \mathrm{n}$. 1).

'The Life of Waller', though written second, is separated from the Lives just discussed by those of Rochester, Roscommon and Otway. Waller lived long into the Restoration period and (in a chronological order by date of death) his life links the first two great political crises of the Lives of the Poets: the Civil War and the 1688 Revolution. Johnson follows the subtle career of Waller during the Civil War period with great interest: Waller had, after all, been a parliamentary critic of the royal measures before the outbreak of war, had withdrawn from the Commons when they 'set royal authority at open defiance' but returned with the King's permission. When Charles set up his standard Waller sent him money, but continued to sit in 'the rebellious conventicle' (I 255-9). These balanced movements formed the foundation of Waller's unsuccessful plot on behalf of the King. Dissimulation, flattery and 
funds then preserved his life but did not save him from exile, and Waller now lived in France, at first in affluence, later in poverty. In the eighteenth century many expected the events of the Civil War and Restoration to repeat themselves, ${ }^{5}$ and this whole sequence of events must have seemed to Johnson a paradigm of the careers of those many later politicians who first opposed James II, then rallied to his cause, funded military attempts of the exiled Stuarts, were their secret supporters in hostile parliaments, and finally went into exile after failed conspiracy. George Granville, Lord Lansdowne, is a good example of the type, and like Lansdowne, Waller eventually returned home to settle under alien rule.

Johnson's judgement of Waller's Panegyric to the Lord Protector is a remarkable synthesis of political principle and literary insight: to adapt an excellent remark by W.J. Bate, political biography turning into criticism. ${ }^{6}$

... he considers Cromwell in his exaltation, without enquiring how he attained it; there is consequently no mention of the rebel or the regicide. All the former part of his hero's life is veiled with shades, and nothing is brought to view but the chief, the governor, the defender of England's honour, and the enlarger of her dominion. The act of violence by which he obtained the supreme power is lightly treated, and decently justified. It was certainly to be desired that the detestable band should be dissolved which had destroyed the church, murdered the King, and filled the nation with tumult and oppression; yet Cromwell had not the right of dissolving them, for all that he had before done could be justified only by supposing them invested with lawful authority. (I 269)

We notice that at the heart of Johnson's concern here is the relation of poetry with law. It is to this end that the passage refuses to take Waller's poem on its own terms only, but insists on seeing it in its historical context. Thus it is at the Restoration that Waller incurs the full force of Johnson's moral verdict. 'It is not possible to read, without some contempt and indignation, poems of the same author, ascribing the highest degree of power and piety to Charles the First, then transforming the same "power and piety" to Oliver Cromwell; now inviting Oliver to take the Crown, and then congratulating Charles the Second on his recovered right ... Poets, indeed, profess fiction, but the legitimate end of fiction is the conveyance of truth; and he that has flattery ready for all whom the vicissitudes of the world happen to exalt must be scorned as a prostituted mind ...' (I 270-71). Here Johnson states his ideal of the poet's moral and religious integrity amid the 
revolutions of state. But if Waller is found wanting Johnson does not scorn the wisdom Waller distilled from being so obsequious in the turns and twists of history. When James II wondered at his marrying his daughter into 'a falling church' Waller thanked the King for noticing his domestic affairs but said he had 'lived long enough to observe that this falling church has got a trick of rising again.' He predicted that James would be left 'a whale upon the strand.' Waller's heir was to join the Prince of Orange (I 275).

The fascinating 'Life of Waller' just overlaps, as we have seen, with that group of Lives which displays the 1688 Revolution and after: Dorset, Dryden, Smith, Sprat, Halifax and Sheffield. Of Dorset Johnson says: 'He received some favourable notice from King James; but soon found it necessary to oppose the violence of his innovations', and 'countenance the Bishops at their Trial' (I 305). 'As enormities grew every day less supportable he found it necessary to concur in the Revolution.' Johnson never questions the reality of the birth of the Prince of Wales. But recognising 'innovations' and 'enormities' Johnson neither praises nor condemns Dorset for his main decision. He speaks of necessity. However, he deprecates the public deception involved in Dorset's escorting the Princess Anne to Nottingham with a guard 'such as might alarm the populace as they passed with false apprehensions of her danger' (I 306). By contrast with Waller and Dorset, Dryden declared himself a papist convert in the reign of James. 'That conversion will always be suspected that apparently concurs with interest' (I 377). Johnson's judgement is reserved by comparison with what he said of Milton or Waller. But now came, for Dryden and his party, one of those times of happiness and hope about which Johnson from the retrospect of nearly a hundred years can be so tellingly sardonic:

Next year the nation was summoned to celebrate the birth of the Prince. Now was the time for Dryden to rouse his imagination, and strain his voice. Happy days were at hand, and he was willing to enjoy and diffuse the anticipated blessings. He published a poem filled with predictions of greatness and prosperity - predictions of which it is not necessary to tell how they have been verified.

A few months passed after these joyful notes, and every blossom of popish hope was blasted by the Revolution. A papist now could be no longer Laureat ... During the short reign of King James he had written nothing for the stage, being, in his own opinion, more profitably employed in controversy and flattery. (I 383-4) 
Johnson again heightens his picture of public opportunism. He later concedes that The Hind and the Panther is a 'work of defiance', more than merely a work of controversy, but at this point in his narrative Johnson gives Dryden no credit for staying faithful to his new faith and his exiled king after 1688 (I 446, 384).

The papist example of Dryden provoked the hostility of Johnson's Church principles. The example of Thomas Sprat, historian of the Royal Society, later Bishop of Rochester, prompts him to express his more complex insights into the dilemma of 1688 . When James II's Declaration of Indulgence 'distinguished the true sons of the church of England, he stood neuter ...'. 'Thus far he suffered interest or obedience to carry him; but further he refused to go'. Yet, 'When king James was frighted away and a new government was to be settled' (note Johnson's circumspect phrasing) Sprat, at a conference to consider whether the throne was vacant, 'manfully spoke in favour of his old master. He complied however with the new establishment ...' (II 35). Sprat was subsequently endangered by allegations of conspiracy against William and Mary which Johnson assumes, perhaps correctly, to have been false.

The record of Charles Montagu, later Earl of Halifax, was very different: 'he signed the invitation to the Prince of Orange,' sat in the convention and praised William's 'victory of the Boyne' (II 42-3). Matthew Prior, his collaborator in that attack on Dryden, The Country Mouse and the City Mouse, was to share the opportunities and promotions of the new regime.

More like the record of Sprat was the mixed experience of John Sheffield, later Duke of Buckingham, and George Granville, later Baron Lansdowne. Neither had the episcopal responsibilities of Sprat. Sheffield got high promotion from King James and, 'having few religious scruples, attended the king to mass and kneeled with the rest, but had no disposition to receive the Romish faith, or to force it upon others.' 'In the Revolution he acquiesced, though he did not promote it.' He was not asked to join the invitation to the Prince of Orange for it was known he would not concur. William later asked what he would have done had he known. "Sir," said he, "I would have discovered it to the king whom I then served." William replied: "I cannot blame you." ' 'Finding king James irremediably excluded,' (note Johnson's language of necessity rather than legality) 'he voted for the conjunctive sovereignty ...' (II 170-71).

It is perhaps the young Granville who came closest to winning Johnson's approval in this Revolution. 'However faithful Granville might have been to the King, or however enamoured of the Queen, he left 
no reason for supposing that he approved either the artifices or the violence with which the King's religion was either insinuated or obtruded. He endeavoured to be true at once to the King and to the Church' (II 287). He displayed this 'regulated loyalty' (Johnson's phrase, II 287) in one of the few letters included in the Lives, where Granville asks his father's permission to take up arms on King James's behalf: " "The King has been misled ... Nobody can deny but he is sacred in his own person, and it is every honest man's duty to defend it" ' (II 288). Not yet a prominent statesman like Sheffield, and the younger son of a younger brother, Granville lived in literary retirement throughout William's reign (II 289). His time of prominence was yet to come.

I conclude this survey of Johnson's depiction of 1688 in The Lives of the Poets with that episode in the career of Edmond Smith (called 'Captain Rag' for his negligence of dress) when Addison invited him, in a tavern, to write what seems intended to have been an official Whig history of the Revolution. " What shall I do with the character of Lord Sunderland?"' he asked, after a pause, Lord Sunderland's son being then Secretary of State. "'When, Rag, were you drunk last?"' asked Addison. Thus Smith lost his great opportunity (II 14).

The question of Johnson's Jacobitism, or Jacobite sympathy, or antianti- Jacobitism, has very fairly been referred by Greene to an assertion in his Introduction to the Political State of Great Britain (1756) where he said that 'the necessity for self- preservation' 'impelled the subjects of James II to drive him from the throne'. 'If a Jacobite is one who thinks James should have retained the English throne, this uncompromising statement may be taken as evidence against the theory that Samuel Johnson had Jacobite tendencies.' Johnson had, in the same place, expressed a measure of appreciation for King James: He was not ignorant of the real interest of his country; he desired its power and its happiness, and thought rightly, that there is no happiness without religion.' His error was to think that 'there is no religion without popery. ${ }^{7}$ The Lives endorse and somewhat qualify the two comments in The Political State. There is the same objection to papist measures ('innovations' and 'enormities') and there is the same resort to a language of necessity rather than of law and choice. If 'self-preservation' be thought to smack of contractual theories of government, the implication is not taken up in The Lives; and Johnson never deploys the Whig concept of a legal deposition of James. Neither does he resort to the popular but fallacious view, grasped at by Tories and Whigs alike, that James had abdicated: Johnson speaks instead of his having been 'frighted away' and 'irremediably excluded. ${ }^{\prime 8}$ Johnson's position is in some respects like that of Swift as recently expounded by F.P. Lock in Swift's Tory Polit- 
ics. In a conflict of principle the safety of the Church comes first. In a situation in which to defend the Church is not also to defend its Governor the King, he recognizes a tragic dilemma in which there was no blameless course. Where a system of moral and political imperatives is felt to have broken down, the language of necessity breaks in. ${ }^{9}$ I suspect that these various points in The Lives of the Poets take us closer to the complexity of Johnson's thought about the Revolution than any of the available political terms, Whig, Tory, Jacobite, etc. But for the record it should be noted that recent reassessment of the Toryism and Jacobitism of this period has revealed, behind the long-lingering labels of Whig historiography, more complex, changing and important political movements than literary scholarship has yet generally recognised. For example, Francis Atterbury, the Jacobite leader in 1722, seems to have regarded the Revolution as the work of Providence, in the same way that a future revolution in favour of the Stuarts would be. And, generally, it was no part of the mainstream of Non-Juror, or Jacobite opinion to deny the false measures of James II, or to defend his judgement. ${ }^{10}$ Yet it is, I suggest, hard not to hear in Johnson's language his personal admiration for those who sought to swim against the revolutionary tide: Bishop Sprat's speaking 'manfully in favour of his old master' and the 'regulated loyalty' of the young poet Granville.

As we read through Volume II of the Lives and into Volume III we find a dispersed group of poets portrayed in relation to the events of Anne's reign, the Hanoverian succession and the consequent social revolution. ${ }^{11}$ 'Upon the succession of the House of Hanover,' Johnson says in the 'Life of Ambrose Philips,' 'every Whig expected to be happy ...' Philips caught 'few drops of the golden shower, though he did not omit what flattery could perform' (III 321). Much more successful was Charles Montague, Baron Halifax since 1698. Halifax, having held high office under William, and under Anne defended occasional conformity, negotiated the Union with Scotland, carried the ensigns of the Order of the Garter to the Elector of Hanover, and on Anne's death having been a regent, was, on the accession of George I, made an Earl, Knight of the Garter, and first commissioner of the Treasury. 'More was not to be had.' In 1715 this consistently Whig politician and man of letters died at the height of his success (II 44-6). Thomas Parnell changed his party 'at the ejection of the Whigs, in the end of queen Anne's reign' (II 50); Samuel Garth, 'an active and zealous Whig', grew familiar with the great when the Whigs were in power, lamented their fall from office, but was knighted 'At the accession of the present Family' (note Johnson's reserved phrase) (II 60- 61).

Joseph Addison's career rose amidst a 'storm of faction' (II 125). Back 
from his travels by 1702 he was soon recruited by Halifax and Godolphin to celebrate the Battle of Blenheim in verse. For reward he was made Commissioner of Appeals; he attended Halifax to Hanover, and became under-secretary of state. Addison is the first great Whig literary figure of the Lives; and it is in his presentation of him that Johnson begins to discuss the phenomenon of party. 'Addison had enough of the zeal for party,' he says; 'Steele had at that time almost nothing else.' The Spectator early showed its party bias (we hear) but soon decided to address itself to general topics (II 92). It 'taught with great justness of argument, and dignity of language, the most important duties and sublime truths' (II 96). Sir Roger de Coverley, Johnson notes, 'appears to be a Tory, or ... an adherent to the landed interest'; Sir Andrew Freeport, 'a new man, a wealthy merchant, zealous for the moneyed interest, and a Whig' (II 97). Neither is treated with the violence that party zeal could at that time sometimes inspire: indeed Johnson notes Addison's proprietorial concern with Sir Roger; also that he has Sir Andrew settle down in the country and adopt a paternal role toward the aged poor.

As the Tories came closer to establishing peace with France, the Whigs grew alarmed and turned again to their chief poet. Johnson tells the tale of Cato with a fine air of ironic detachment and, not quite, impartiality:

The time ... was now come when those who affected to think liberty in danger affected to think likewise that a stage-play might preserve it ...

Now, "heavily in clouds came on the day, the great, the important day", when Addison was to stand the hazard of the theatre. That there might, however, be left as little to hazard as was possible on the first night, Steele ... undertook to pack an audience ...

The danger was soon over. The whole nation was at that time on fire with faction. The Whigs applauded every line in which Liberty was mentioned, as a satire on the Tories; and the Tories echoed every clap, to shew that the satire was unfelt. The story of Bolingbroke is well known. He called Booth [who played Cato] to his box, and gave him fifty guineas for defending the cause of Liberty so well against a perpetual dictator. The Whigs, says Pope, design a second present, when they can accompany it with as good a sentence.

The play, supported thus by the emulation of factious praise, was acted night after night ... (II 99-101) 
From the mock-heroic application of the first lines of Cato to Addison's theatrical ordeal, to the brilliant remarks of Bolingbroke and Pope, Johnson so frames his narrative as to mock the great Whig propaganda triumph and, while standing back from faction, to give the Tories the last word. ${ }^{12}$

The Whigs soon had a more real triumph. The 'House of Hanover took possession of the throne' (note Johnson's rather bold phrase) and Addison became secretary of the regency, which required him 'to send notice to Hanover that the Queen was dead, and that the throne was vacant. To do this would not have been difficult to any man but Addison, who was so overwhelmed with the greatness of the event and so distracted by choice of expression' - that the regents gave the job to a clerk (II 108-9). This 'idle tradition' (as Macaulay called it in his essay on The Life and Writings of Addison in 1843) offers a not unsympathetic insight into the man, and supplies, I think, a unique moment in the story of poets and affairs of state. Addison was more at home in The Freeholder (1715-16) in which he is rebuked by Johnson for mocking the poverty of the exiled Stuart claimant and compared, significantly enough, with Milton who had done the same. Soon Addison reached 'his highest elevation': secretary of state. Here (according to Johnson) he was unequal to his task and (according to Macaulay) resigned through ill health. 'What he gained in rank, he lost in credit', says Johnson, in a satirical sentence echoing Dryden. ${ }^{13}$

The last state episode in the 'Life of Addison' concerns his quarrel with Steele over the Peerage Bill, 1719. Here Johnson might have said, as he was to do in his 'Life of Akenside', 'my business is with his poetry' (III 417) but his first full-scale Whig Life could hardly omit this specially telling Whig dispute. The Bill proposed to limit the prerogative of the Crown by fixing the number of peers: there were to be no more than six new creations save on the extinction of an old peerage family. The Lords favoured the proposal; the King was too new to his throne to see what the Crown would relinquish; only the Commons opposed. Johnson rightly saw the measure in the context of recent party expediency but had his Tory answer to Whig complaint:

The lords might think their dignity diminished by improper advancements, and particularly by the introduction of twelve new peers at once, to produce a majority of Tories in the last reign; an act of authority violent enough, yet certainly legal, and by no means to be compared with that contempt of national right, with which some time afterwards, by the instigation of Whiggism, the commons, chosen by the people for three years, chose themselves for seven. (II 114) 
Together with consistent patronage of the Hanoverian crown, the Septennial Bill (to which Johnson here refers) was to be one of the two pillars of the Whig hegemony from 1715-60. Johnson is evidently the opposition Tory when he homes in on this point; and it is telling too that he sides with Steele and Robert Walpole in opposing a third measure to entrench Whiggism: which (in Steele's words) would have introduced 'an aristocracy; for a majority in the house of lords so limited would have been despotick and irresistable.' As a serious Tory, Johnson is not afraid to side with Whigs like Walpole and Steele in the greater cause of crown and people. The decorous and prudent Addison, by contrast, lent his pen to 'this subversion of the ancient establishment.' Thus Addison and Steele, 'these two illustrious friends', after so many years, parted 'in acrimonious opposition' (II 115). ${ }^{14}$

How does Johnson depict other poets during Anne's reign and the Whig revolution of 1715-17? John Hughes, who had published poems in praise of William, wrote for Addison and Steele and ended in 1717 as secretary to the Commission of the Peace. Sheffield, having promoted the Union, was made Duke of Buckingham, opposed Marlborough, joined the Tories and was Lord Chamberlain of the Household when the Tories came in in 1710 . Prior, who had written poems in praise of William and of the victories of Anne, was also an experienced diplomat. When the nation grew weary of the war as the Queen of her Whig ministers, and the Tories hoped to gratify both Queen and people, Prior put his services at their disposal and helped to negotiate the Treaty of Utrecht. On the downfall of the Tories he was taken into custody and interrogated in the hope of incriminating Oxford, now imprisoned in the Tower; but Prior managed to hold out against the Privy Counsel committee. Walpole moved for an impeachment, unsuccessfully, but Prior was two years in custody and was excluded from the Act of Grace of 1717. Rewarded for his loyalty to Oxford by the gift of Down Hall, he at last gained a measure of prosperity with publication of his poems by a very popular subscription.

Congreve, who enjoyed the patronage of Whigs, was allowed by Oxford to keep his place under the Tories, but further rewarded by Whigs on their return to power. Blackmore believed himself to have helped bring about the Hanover succession (II 240).

Elijah Fenton 'with many other wise and virtuous men, who at that time of discord and debate consulted conscience, whether well or ill informed, more than interest ... doubted the legality of the government, and, refusing to qualify himself for publick employment by the oaths required, left the university without a degree' (II 257). But, as Johnson also says, his opinions as a Non-juror not being 'remarkably 
rigid' (II 258) Fenton published poems in praise of Anne and even Marlborough at the height of his glory. His Horatian Ode to Lord Gower, on the other hand, which Johnson tells us Pope thought ' the next ode in the English language to Dryden's Cecilia' (II 264), must in fact have been written to console and fortify Gower's spirits on the defeat of the Jacobite Rebellion in 1715, which he was just too late to join before it collapsed. ${ }^{15}$ Another poet on the edges at least of Jacobitism (though Johnson does not say so) was Granville. 'When the violence of party made twelve peers in a day' Granville, 'by a promotion ... not invidious' (II 291) was created Baron Lansdowne. In 1712 he was high in the Queen's favour, comptroller of the household and a privy counsellor, and was soon to be treasurer of the household (II 292), but 'lost all but his title' 'at the accession of King George' and 'was persecuted with the rest of his party. Having protested against the bill for attaining Ormond and Bolingbroke he was, after the insurrection in Scotland, seized, Sept. 26, 1715, as a suspected man, and confined in the Tower till Feb. 8, 1717, when he was at last released, and restored to his seat in parliament; where (1719) he made a very ardent and animated speech against the repeal of the bill to prevent Occasional Conformity ...' (II 292). It is likely that Johnson was aware of Granville's later efforts to secure a Stuart restoration, especially during the Atterbury Plot in 1722, but of this we hear nothing. Yet Granville spent the next ten years abroad (for reasons of economy, says Johnson) returning only in 1732 when 'he now went to Court' (II 293). Granville underwent similar, if less severe, political vicissitudes to Waller; yet this Waller- like poet was less of a turncoat, more inwardly constant, if outwardly something of a trimmer. ${ }^{16}$

Thomas Yalden, friend of both Addison and Sacheverell at Magdalen College, praised William on his victory of Namur, and Anne on her accession. He was a quiet high-church rector when, 'at the clamour raised about Atterbury's plot' 'Every loyal eye was on watch for abettors or partakers of the horrid conspiracy; and Dr. Yalden, having some acquaintance with the bishop, and being familiarly conversant with Kelly his secretary, fell under suspicion, and was taken into custody' (II 300). This, like the similar episode in the Life of Sprat, is another tale of unjust accusation by the established Whigs. Johnson tells the tale with a terse irony that reaches back into the official phrase 'horrid conspiracy' used above.

Thomas Tickell, called 'Whiggissimus' by Swift (II 306), is not shown by Johnson to have much party committment at the time of the Tory peace. But, 'when the Hanover succession was disputed Tickell gave what assistance his pen would supply.' His anti-Jacobite Letter to Avig- 
non 'stands high among party poems: it expresses contempt without coarseness, and superiority without insolence' (II 310). Politically speaking, the contrasted lives of Yalden and Tickell (the former one of those added at Johnson's suggestion) make a significant contribution to the Lives as a whole.

So too does the 'Life of Swift' which, like that of Addison, is fully conceived in the party terms of Whig and Tory. These are the two great political Lives of the later historical period of the work. The story opens with William III who showed Swift how to cut asparagus in the Dutch way, and offered to make him a captain of horse (III 4). This king was the subject of an ode by Swift, whose hopes were, however, disappointed. As time passed he acknowledged authorship of certain works in defence of the Church. He applied (on behalf of the Church of Ireland) to Harley, when the Tories came into power, 'as a man neglected and oppressed by the last ministry' and was admitted to his confidence though 'not immediately considered as an obdurate Tory' (III 14-15) and still on terms with Steele and other Whigs. In 1711 he wrote his 'Letter to the October Club' a number of 'Tory Gentlemen sent from the country to Parliament ... and met to animate the zeal and raise the expectations of each other. They thought, with great reason (Johnson revealingly says), that the Ministers were losing opportunities; that sufficient use was not made of the ardour of the nation; they called loudly for more changes, and stronger efforts ... Their eagerness was not gratified by the Queen, or by Harley. The Queen was probably slow because she was afraid; and Harley was slow because he was doubtful: he was a Tory only by necessity, or for convenience ... he corresponded at once with the two expectants of the Crown [that is George the Electoral Prince, and James Edward, the Old Pretender], and kept, as has been observed, the succession undetermined. Not knowing what to do, he did nothing; and, with the fate of a double dealer, at last he lost his power, but kept his enemies' (III 16-17). The reader of this passage must note how decisively Johnson does not share Swift's and Pope's admiration for Harley. The passage is, of course, discreetly structured: the student of Johnson's opinions may ask whether the author of the earlier Lives would have approved had Harley been decisively Hanoverian; and, if this seems unlikely, what course would Johnson have desired? At any rate, Swift was in Johnson's eyes 'at the zenith of his political importance' on the publication in 1712 of The Conduct of the Allies and Johnson adds his concurrence to the Tory view of the War: 'That is no longer doubted, of which the nation was then first informed, that the war was unnecessarily protracted to fill the pockets of Marlborough; and that it would have been 
continued without end, if he could have continued his annual plunder' (III 18). Swift now became 'formidable to the Whigs' (III 25) but was unable to reconcile the two Tory leaders, and, retiring from the scene, was awaiting the outcome of this division, when 'the death of the Queen broke down at once the whole system of Tory politicks; and nothing remained but to withdraw from the implacability of triumphant Whiggism' (III 26). Johnson here insists on what some of the most recent historians of the eighteenth century have argued: that the coming George I marked not just the disappointment of the Jacobite Tories, but the establishment of a new 'system' of politics. ${ }^{17}$ Johnson goes on to outline Swift's later conflict with 'Whiggism' as M.B. Drapier, mentions how he kissed the hands of George II and Queen Caroline in 1727, and, unusually, introduces political terms into the critical section of the Life: 'When Swift is considered as an author it is just to estimate his powers by their effects. In the reign of Queen Anne he turned the stream of popularity against the Whigs, and must be confessed to have dictated for a time the political opinions of the English nation. In the succeeding reign he delivered Ireland from plunder and oppression, and shewed that wit, confederated with truth, had such force as authority was unable to resist' (III 50). 'By his political education he was associated with the Whigs, but he deserted them when they deserted their principles, yet without running into the contrary extreme; he continued throughout his life to retain the disposition which he assigns to the "Church- of-England Man," of thinking commonly with the Whigs of the State, and with the Tories of the Church' (III 52-3). In the light of these judgements it seems to me that, while doubtless Johnson did not wholly approve of Swift's 'political activities', it is wide of the mark to claim, with Greene, that Johnson's attitude to Swift's 'political involvements' 'is far from one of admiration. ${ }^{\prime 18}$

Swift's career carried Johnson well into the eighteenth century, and into his own literary lifetime. The remaining Lives in the chronological sequence complete the poetic and political picture. He is inclined to endorse Pope's claim to have been his own man, 'While Tories call me Whig, and Whigs a Tory' but still notices the dangers in which Pope lived: Pope's unsuccessful attempt to support Atterbury at his trial in 1723; his detection of Voltaire as an informer; how he was intended to be intimidated by the arrest of the poet Paul Whitehead (III 140- 41, 144, 180-81). The Pope of the 'Epilogue to the Satires', however, Johnson sees as having abandoned the prudence with which he had earlier passed 'uninjured and unoffending' 'through much more violent conflicts of faction': he was now 'entangled in the opposition' (III 179). 
Johnson, who Boswell tells us changed his opinion of Walpole after the political watershed of $1760,{ }^{19}$ expresses his view of the patriot opposition in the Lives of Thomson and Lyttelton. 'At this time a long course of opposition to Sir Robert Walpole had filled the nation with clamours for liberty, of which no man felt the want, and with care for liberty, which was not in danger' (III 289). 'Lyttelton now stood in the first rank of opposition; and Pope, who was incited, it is not easy to say how, to increase the clamour against the ministry, commended him among the other patriots ... At length, after a long struggle, Walpole gave way, and honour and profit were distributed among his conquerors. Lyttelton was made (1744) one of the Lords of the Treasury; and from that time was engaged in supporting the schemes of the ministry' (III 488-89). Johnson is less severe on the Whig Akenside's 'unnecessary and outrageous zeal' for what he called and thought liberty (III 411) than on the last phase of the opposition to Walpole to which he himself had contributed.

The foregoing survey suffices to show, first, that the Lives of the Poets have a powerful political preoccupation, by no means confined to a few Lives and a few provocative sallies. I have mentioned twenty-six Lives, not including the great Life of Savage on which I shall touch in conclusion. Johnson's vision of the poet in the world sees him borne on the streams of political history; sometimes swimming with, sometimes against, sometimes briefly, directing, its currents. Secondly, the Lives show Johnson's own views of English history. His strictures on Milton and Cromwell, at least, are never forgotten; and all but the most ideological eighteenth-century whigs would have concurred. His treatment of 1688 is different: his feelings divided, his insight tragic, and the language with which he refers to the departure of King James tellingly reticent. He stresses inevitability rather than right and never claims, as Whigs did at the Sacheverell Trial, that the King was legally deposed. He supports Swift's case for the Tory Peace in 1712 and endorses the analysis of the October Club. On the Hanoverian revolution of $\mathbf{1 7 1 5}$ he is reticent as to the right of 'the present family' which 'took possession' of the throne in that year, but explicit on the fate of the then persecuted and proscribed Tories. He roundly condemns the unconstitutional nature of the Septennial Act of 1717, and the proposed Peerage Bill. Like some prominent Jacobite Tories such as William Shippen he came to dislike the Whig Patriots who, merely for office, opposed Walpole at the end of his career ('I will not pull down Robin on republican principles' said Shippen, on the motion for the removal of Walpole in 1741). ${ }^{20}$ From the retrospect of the later eighteenth century he defends Walpole's record. And in all Johnson's eighteenth- 
century political discussion he speaks in terms of Whig and Tory, which he simply defines in the Life of Addison through the characters of Sir Roger de Coverley and Sir Andrew Freeport (II 97): he hardly uses the alternative terminology of Court and country. ${ }^{21}$

Where Jacobitism is concerned, Johnson records less than he knows. For example, he was certainly aware of the Jacobite leanings of Lord Gower, ${ }^{22}$ but does not use his knowledge to explicate Fenton's 1716 Ode to Gower. He is unlikely to have been ignorant that Savage, about the same time, had written explicit Jacobite poetry but the Life (written in 1744 when Jacobite politics were serious and dangerous) says nothing of this. Any knowledge he had of the Jacobite designs of various friends of Pope, Granville, Buckingham, Atterbury, Cornbury and others was unused. Equally Charles Churchill, who had attacked Johnson after 1760 as a Jacobite turncoat, was excluded from the Poets, apparently at Johnson's request. ${ }^{23}$ It was Johnson's decision, in his last major work, to keep silent on this old and now settled conflict and to write as a loyal subject of George III. He recognised that he had been partisan in other respects. 'If the King is a Whig he will not admire it,' he wrote of The Lives, 'but is any King a Whig?'24

Richard Savage wrote, in 1715-17, poetry as explicitly Jacobite as any poet in the Lives - so far as we know. 'Rouse up once More for Royal James's Sway,/St. George in George shall the Land's Dragon slay;' he had proclaimed in Britannia's Miseries, probably in late 1716. ${ }^{25}$ Johnson's friendship with Savage, of course, belongs to the period of his own bitter hostility to the Whig hegemony and the supremacy of Walpole. It was during this period that, in a well- attested report, he walked all night in St. James's Square with Savage, 'not at all depressed by their situation; but in high spirits and brimful of patriotism ... inveighed against the minister, and "resolved they would stand by their country."'26 Savage, despite his long and open poetic courtship of patronage from Hanoverian court and Walpolean whig, never dissembled - at least to Johnson - his real views, 'as an advocate for the ministry of the last years of Queen Anne' and 'always ready to justify the conduct and exalt the character of Lord Bolingbroke ...' (II 392). Savage's situation displayed with cruel clarity the predicament of the poet whose principles pointed in one direction, but his need in another. Indeed the Tory and sometime Jacobite Savage underlined the dilemma of many a Tory out of place between 1715 and 1760 . His very titles express deracination: The Bastard, The Wanderer, Author To Let, Volunteer Laureate.

There may be more to this. Ever since it has been known that the pretender Savage was probably not 'son of the Earl Rivers', as Johnson's 1744 title page had affirmed, it has seemed strange that one who knew 
the world as well as Johnson did should have credited what we are not even quite sure Savage himself believed. ${ }^{27}$ Savage stood to gain much from his well publicised grievance, with its appeal to the principle of heredity, the status of rank, and the fact of a child's innocence. Yet may not these very features of Savage's claim have appealed to Johnson as exemplary of a much wider misfortune in Hanoverian Britain? Was Savage not (if his claim were credited) a symbol of disinherited right, with all the wordly humiliations and peculiar moral challenges consequent upon that? This is the same Johnson who was to chastise Milton and Addison for mocking the poverty of the exiled Stuarts. Not for nothing (one may think) did Johnson linger over the relative rights of the Church (the ecclesiastical Court of Arches) and the secular court of Parliament to annul the marriage of the Earl Rivers and the Countess of Macclesfield. Did Parliament have the right, in any religious or absolute sense, to disinherit, illegitimate - Richard Savage or anyone else? Savage's tale, whether Johnson or Savage believed it or no, accorded in with the configuration of Johnson's historical and political outlook, as this may be reconstructed from his earlier writings, and other, pre-Boswellian sources such as Sir John Hawkins's Life.

Johnson's compassionate and indomitably judicious approach to the revolutions of Savage's career, the misfortunes, faults and almost invincible hopes, is, called forth by a variety of circumstance, to be found throughout the Lives. What impresses is how Johnson's capacity for a certain justice, moral and aesthetic, overrides his principled and thoughtful Tory outlook. This can be seen in large and small matters alike. Paradise Lost is not condemned despite Johnson's view of its author's career, and the opportunities which life and poem together might have offered a lesser man. The Non-Juror Fenton does not evade notice for writing flattering poems to Queen Anne and Marlborough: Johnson had been a Non-Juror without flattering. That decent but deeply party writer Addison is credited with decency, and piety too. Johnson's critical approval is not 'bribed' (as he thought perhaps Pope's had been by the subject of The Hind and the Panther) by his moral and political approval of the lives of Granville and Swift. Johnson's quest for integrity in poets amidst the revolutions of state is endorsed by the implacably independent acuity and candour of his own judgement. In the act of writing itself (almost always) he practised what he preached.

HOWARD ERSKINE-HILL

Pembrooke College, Cambridge 


\section{NOTES}

I gratefully acknowledge the advice of Professor Ian Jack, Mr. C.G. Clingham, Mr. Peter Swaab, and Dr. J.C.D. Clark, who do not necessarily endorse my views, and of course are not responsible for any errors in this essay. Samuel Johnson is a key figure in Dr. Clark's English Society 1688-1832: Ideology, social structure and political practice during the ancien regime (Cambridge 1985), a challenging and important book of which those who write on literature and politics in the eighteenth century will need to take account.

1. Donald J. Greene, The Politics of Samuel Johnson (New Haven: Yale University Press, 1960), pp. 221-2, says that the Lives "contains some amusing glances at the politics of his subjects. But such obiter dicta are not very frequent. The most politically significant passages are those in the lives of Milton, Waller, and Butler."

2. For example, in: Paul Fussell, Samuel Johnson and the Life of Writing (New York: Harcourt Brace, 1971), Ch. 9; W. Jackson Bate, Samuel Johnson (London: Chatto \& Windus, 1978), Ch. 29; Robert Folkenflik, Samuel Johnson, Biographer (Ithaca and London: Cornell University Press, 1978); and J.P. Hardy, Samuel Johnson: A Critical Study (London: Routledge and Kegan Paul, 1979), Ch. 8. It may be thought, however, that political themes hardly fall within the schemes of Fussell and Hardy; the need is most felt in Bate, whose few political pages are devoted to trying to dispel modern misunderstandings of eighteenth-century Toryism (pp. 189-99). For a major biographer of Johnson, Bate is not as strong as one could wish on the world in which Johnson lived. The relative neglect of the present topic is even found in John A. Vance's recent Samuel Johnson and the Sense of History (Athens, U.S.A., 1984), though the few pages he devotes to the Lives show a sharp eye for the important political judgement, eg. pp. 103-7. Vance is right to observe that Johnson 'on occasion offers historical information or analysis beyond what is required of a good literary critic or biographer' (p. 104). See also Maximilian Novak, 'Johnson, Dryden and the Wild Vicissitudes of Taste' in Burke and Kaye, ed. The Unknown Samuel Johnson (Madison, Wisc.: University of Wisconsin Press, 1983), pp. 54-75.

3. See Conrad Russell, The Crisis of Parliaments (Oxford, 1971) and Conrad Russel, ed. The Origins of the English Civil War (1973). Also G.E. Aylmer, ed. The Interregnum: The Quest for Settlement, 1646-1660 (London, 1972) and Howard Erskine-Hill and Graham Storey, ed. Revolutionary Prose of the English Civil War (Cambridge: Cambridge University Press, 1973), pp. 1-12.

4. Arthur Sherbo, ed. Johnson on Shakespeare (The Yale Edition of the Works of Samuel Johnson) (New Haven: Yale University Press, 1968), VII 65.

5. See D. Szechi, Jacobitism and Tory Politics, 1710-14 (Edinburgh: John Donald Publishers Ltd., 1984), pp. 36-42; and, more generally, Howard Erskine-Hill, The Augustan Idea in English Literature (London: E. Arnold, 1983), pp. 350-53.

6. W.J. Bate, The Achievement of Samuel Johnson (New York: Oxford University Press, 1955), p. 185.

7. Donald J. Green, ed. Samuel Johnson, Political Writings in The Yale Edition of the Works (New Haven, 1977), X 142-3 and n. 8; 193 and n. 3. 
8. See J.P. Kenyon, Revolution Principles: The Politics of Party, 1689-1720 (Cambridge: Cambridge University Press, 1977); Howard Erskine-Hill, 'Literature and the Jacobite Cause: Was There a Rhetoric of Jacobitism?' in Eveline Cruickshanks, ed. Ideology and Conspiracy: Aspects of Jacobitism, 1688-1759 (Edinburgh: John Donald Publishers Ltd., 1982); and Mark Goldie, 'The Revolution of 1689 and the structure of Political Argument: An Essay and An Annotated Bibliography of the Pamphlets on the Allegiance Controversy', Bulletin of Research in Humanities, LXXXIII (1980), 473-564, on the various attitudes to the 1688 Revolution in the 1690 s and after.

9. F.P. Lock, Swift's Tory Politics (London: Duckworth, 1983), Ch. 2.

10. For Atterbury, see Szechi, Jacobitism and Tory Politics, pp. 42-4; and G.V. Bennett, The Tory Crisis in Church and State, 1688- 1730 (Oxford: Clarendon Press, 1975), pp. 104-5. Once the House of Hanover was established in England, and its policies known, the Jacobite movement received a powerful new practical impetus: see Eveline Cruickshanks, Political Untouchables: The Tories and the ' 45 (London: Holmes and Meier, 1979), Ch. 1; and, behind her arguments, her work and that of others in Romney Sedgwick, ed. The History of Parliament: The House of Commons, 1715-54 (London: H.M.S.O., 1970).

11. The notion of the proscription of the Tories as a social revolution is that of Eveline Cruickshanks, The Untouchables, pp. 4-5.

12. Addison hardly meant Cato to be a political allegory. M.M. Kelsall, 'The Meaning of Addison's Cato', R.E.S., N.S. XVII 6 (May 1966), 149-62, is certainly right that the main thrust of the drama is that of Roman public morality of a stoic and republican kind. Addison intended to present a play of general relevance to the times rather than dramatise contemporary history. But the rage of party clamoured for applications.

13. 'What we gain'd in skill we lost in strength', 1.12 of 'To My Dear Friend Mr. Congrave on His Comedy The Double Dealer', The Poems of John Dryden, ed. James Kinsley (Oxford, 1956), II 852.

14. On the Peerage Bill crisis see the anonymous article, 'The Peerage Bill in $1719^{\prime}$, in The Retrospective Review ... ed. Henry Southern and Nicholas Harris Nicholas, 2nd. Series, II (1828), pp. 18-135; and E.R. Turner, 'The Peerage Bill of 1719', in The English Historical Review, ed. R.L. Poole, XXVIII (1913), pp. 243-59. I owe these references to Dr. J.C.D. Clark.

15. An ode to the Right Hon. John Lord Gower. Written in the Spring, 1716 was not included in Fenton's Poems (1717), perhaps because of the political occasion disclosed in its subtitle. Lord Gower was at this time a known Jacobite sympathiser who in 1715 seems to have set out to join the Jacobite army at Preston but turned back on hearing of its surrender (Eveline Cruickshanks, Political Untouchables, p. 7). The poem is carefully designed to welcome peace, perhaps even to console at its prospect, thus salvaging the honour of Gower who might seem to have played no very heroic part in the Rebellion. Thus the Ode glances at various current and recent foreign wars, including that between Charles XII of Sweden and the Czar:

Beneath the pole on hills of snow Like Thracian Mars, the' undaunted Swede 
To dint of sword defies the foe;

In fight unknowing to recede:

only to announce that 'here no clarion's shrilling note/The Muse's green retreat can pierce ...'. At the same time Fenton seeks to fortify Gower in his Tory and royalist ideology, drawing inspiration from classical antiquity and from several royalist martyrs and exiles of the English Civil War and after:

O flower of ancient English faith, Pursue the' unbeaten patriot path, In which confirm'd thy father shone ...

Honour's bright dome, on lasting columns rear'd, Nor envy rusts, nor rolling years consume;

Loud paeans echoing round the roof are heard, And clouds of incense all the void perfume.

There Phocion, Laelius, Capel, Hyde, With Falkland seated near his side, Fix'd by the Muse, the temple grace: Prophetic of thy happier fame, She, to receive thy radiant name, Selects a whiter space.

There is nothing treasonable in this skilful and courtly poem: apart from welcoming peace, the poem's choice of loyal examples is unexceptionable. Hanoverian kings would hope to be the object of loyalty like that of Capel, Hyde and Falkland, if need be. At the same time Jacobitism drew much of its spirit and hope from the way the Restoration had seemed to vindicate those who suffered death and exile for the Stuarts in the Civil War (Bruce Lenman, The Jacobite Risings in Britain 1689-1746 (London: Eyre Methuen, 1980), pp. 11-27; D. Szechi, Jacobitism and Tory Politics 1710-14 (pp. 34-41). It is this harping on martyrdom, at a time when a rebellion had been successfully overcome, which reveals the poem's Tory and Jacobite ideology. Inspired by martyrs, Gower will not however be among them. For him the Muse predicts something just as honourable but much more fortunate: the fulfilment of his political hopes.

16. See Elizabeth Handasyde, Granville the Polite (Oxford, 1938) for Granville's Jacobite career and ultimate reconciliation with the Hanoverian line.

17. See especially J.C.D. Clark, 'A General Theory of Party, Opposition and Government, 1688-1832', Historical Journal, XXXIII (1980), 295-325.

18. Greene, The Politics of Samuel Johnson, p. 222.

19. See Howard Erskine-Hill, 'The Political Character of Samuel Johnson', in Isobel Grundy, ed. Samuel Johnson: New Critical Essays (London and Totowa, N.J.: Vision and Barnes \& Noble, 1984), p. 125; James Boswell, Life of Johnson, ed. Birkbeck Hill (Oxford: Oxford University Press, 1934), I 129-31. 
20. Romney Sedgwick, ed. The History of Parliament: The Commons, 1715-54, II 423.

21. See W.A. Speck, Tory and Whig (London: MacMillan, 1970) and Stability and Strife 1714-60 (London: Arnold, 1977) for the view that 'Court and Country' rather than 'Whig and Tory' are the best terms for the structure of eighteenth-century politics. Johnson gives little support to this view.

22. As is shown by his inclusion of Gower's name in the Dictionary under the entry for 'Renegade'. Gower not only abandoned his Jacobitism, and sought and accepted office in the early 1740s, but raised a regiment for the Government in 1745 (GEC Peerage, VI 36-7). For comment on the significance of Gower for Johnson see Greene, The Politics of Samuel Johnson, pp. 15-16, and Howard Erskine- Hill, art. cit. pp. 112, 134.

23. Hester Lynch Piozzi, Anecdotes of the Late Samuel Johnson, LLD ... ed. Arthur Sherbo (London: Oxford University Press, 1974), pp. 121-2. Thraliana: The Diary of Mrs. Hester Lynch Thrale (later Mrs. Piozzi), 1776-1809, ed. K.C. Balderston (Oxford: Clarendon Press, 1943), p. 203. Mrs. Thrale is clear on Johnson's responsibility for the exclusion of Churchill from the small- volume edition of the Poets in Thraliana: 'He was however very much nettled by Churchill's Satire [The Ghost] that's certain; for he rejected him among the Poets when the Booksellers begged him a Place in the Edition they are now giving in small Volumes ...'. Her position as to Johnson's motive is qualified when she comes to print her Anecdotes. Balderstone assumed that it was the attack on Johnson's credulity, and on his Shakespeare subscription, which 'nettled' Johnson. But Churchill's assault on Johnson as a Jacobite was far more serious.

24. Johnson to Mrs. Thrale, 10 March 1779; The Letters of Samuel Johnson, ed. R.W. Chapman (Oxford: Clarendon Press, 1952), II 606.

25. L1. 71-2; The Poetical Works of Richard Savage, ed. Clarence Tracy (Cambridge, England: Cambridge University Press, 1962), pp. 22, 15-16.

26. W.J. Bate, Samuel Johnson, p. 179, 611.

27. The complex question of Savage's parentage was re-examined by Clarence Tracy in The Artificial Bastard: A Biography of Richard Savage (Toronto, 1953), $\mathrm{Ch}$. I. He concluded that 'whatever the truth may have been, Savage believed what he said' (p. 27). This seems probable; yet the uncertainty we are in as to the truth of Savage's claim itself may be thought to leave his motives still vulnerable to question. Sir John Hawkins, Boswell and Mrs. Piozzi, admittedly late witnesses, were all dubious about Savage's case; Mrs. Piozzi remarking that Johnson 'was not difficult to be imposed on where the Heart came in question' (p. 4). It is a comment worth pondering. 